\title{
Jalāl al-Dīn ‘Abd al-Roḥmān ibn Abī Bakr al-Suyūṭī
}

\author{
Adib Rifqi Setiawan

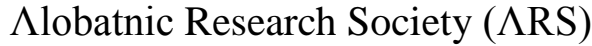 \\ J1 Kudus - Colo, km. 19, Pandak 001/003, Colo, Kudus, 59353, Indonesia \\ adibrifqisetiawan@gmail.com
}

\begin{abstract}
This memorial article was wrote in memory of one of my loved one, Jalāl al-Dīn 'Abd alRoḥmān ibn Abī Bakr al-Suyūṭ̣̂, born on Sunday, 1 Rojab 849 AH / 3 October 1445 CE and passed away on 19 Jumāda al-Ülā 911 AH / 18 October 1505 CE.
\end{abstract}

Keywords : al-Suyūṭī; Islamic studies; scholar;

Jalāl al-Dīn 'Abd al-Roḥmān ibn Abī Bakr al-Suyūṭ̂i is represented in virtually every genre of scholarly and literary production that existed during the Saltonat al-Mamālîk age. He was recognized as the most prolific author in the Islamic studies, past and present, nor the most controversial one of his time. His remarkable faith in his own judgments, his mocking rebuttals, and his personal attacks on those who disagreed with him all earned him the ire of his fellow scholars. He believed himself to be the most learned man of his time, and this as well as even bolder claims that he made polarized his contemporaries into ardent supporters versus vehement adversaries. The controversy over the value of his contribution to scholarship continues to this day.

Al-Suyūṭ̂̄'s life has been described in great detail elsewhere, e.g. his own autobiography entitled al-Tahadduts bi-Ni 'mat Allōh Ta'ālā and his entry in Husn al-Muhādhoroh fi Tārikh Mișro wa al-Qōhiroh', 'Abd al-Qōdir al-Syādzilī's Bahjat al-'Ābidīn', nor a commentary of his autobiography by Elizabeth Mary Sartain ${ }^{4}$ that reviewed by Harry T. Norris ${ }^{5}$. Thus, here it is necessary to give only a brief outline.

'Abd al-Roḥmān ibn Abī Bakr ibn Muḥammad ibn Khị̣̂ ibn Ayyūb ibn Muhammad ibn alHumām Jalāl al-Dīn al-Khuḍayrī al-Suyūṭ̂̄ was born on Sunday, 1 Rojab 849 AH / 3 October 1445 CE. His mother, a Circassian woman, was said to have given birth to him in the family library, where his father had sent her to retrieve a book; hence his prophetic nickname "ibn al-kutub" (son of books). Al-Suyūṭ̂̄'s father, Kamāl al-Dīn Abū Bakr, a scholar, died while al-Suyūṭ̄ was a small child, but guardians made sure that the boy received the education usual for one of his background, beginning with memorizing the Quran and proceeding to the various religious sciences, grammar, adab, and Shafi' $i$ jurisprudence. He was given his first ijäzah to teach grammar and $a d a b$ at the age of sixteen, and by the following year had been given permission to teach Shafi'i jurisprudence and issue fatwás by the chief qadi, 'Alam alDīn Șālih al-Bulqīnī. At the age of eighteen al-Suyūṭi inherited his father's former post as professor of Shafi'i jurisprudence at the mosque of Shaykhū, and later added the post of teacher of hadith at the Shaykhūniyah. He also was appointed to two other positions which seem to have been administrative rather than instructional: shaykh of sufis at the mausoleum of Barqūq al-Nāṣirī, and supervisor of the Baybarsīyah khonqōh.

4 (Sartain, 1975)

(السيوطي، (1970) (1978) (1970)

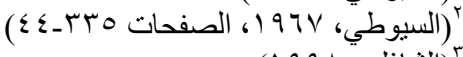

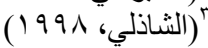

5 (Norris, 1976) 
Even as al-Suyūțî's scholarly fame began to spread abroad, his career in Egypt became mired in numerous disputes. Disagreements with other ulama on specific points of theology and law invariably degenerated into reciprocal personal attacks. There were also a number of widespread controversies (which involved the entire community of the ulama and in some cases the amirs and up to the sultan himself) into which al-Suyūṭ̂̄ waded, including the question of the orthodoxy of the famous sufis Ibn al-Fārị̣ and Ibn al-'Arabī (al-Suyūṭ̂̄ defended it) and the question as to whether or not women would see God in the afterlife (alSuyūtị denied that possibility). His contentiousness and irascibility progressed to the point that he refused to pay the customary monthly courtesy call on the sultan Qōytbāy in order to receive personally his stipend as shaykh of the Baybarsīyah khonqōh, citing the practice of the early pious Muslims in refusing to frequent wordly rulers. This incident provides a good example of al-Suyūțī's wont to vindicate his actions by writing one or more books.

In the late $890 \mathrm{~s} / 1480 \mathrm{~s}$, al-Suyūțī began to withdraw from public life. He progressively resigned from his various teaching and administrative posts and stopped delivering fatwás. In 906/1501 he was dismissed from his post at the Baybarsiyah khonqōh following acrimonious disputes with the sufis there, and when the sultan Țūmānbāy, in support of the sufis, sought to have him killed he went into hiding. These reached the point that the sufis "rose up against their shaykh ... and almost killed him, then they carried him in his clothes and threw him into the fountain." "Upon the sultan's death al-Suyūṭi reappeared but retreated completely to his house on Rawdiah Island, announcing that he was devoting himself to God, refusing to leave the house and receiving visitors only reluctantly. There he remained, writing and revising his works, until his death on 19 Jumādá I 911/18 October 1505.

There can be no doubt that he was endowed with an incredibly agile and retentive mind. $\mathrm{He}$ claimed to have memorized 200,000 hadiths, which were all that had come to his attention; if he had located more, he would have memorized them as well. In speed of writing and composition al-Suyūṭ̂ was "one of the great signs (âyāt) of God," and he was able to edit and dictate several works simultaneously; his pupil Dāwūdī is reported to have said: "I have seen the shaykh write three quires in one day, both composing and writing down, as well as dictate hadith and answer opponents."

Quite early in his scholarly career al-Suyūṭi claimed special expertise in a number of subjects: "I was endowed with deep penetration in seven sciences: Quran commentary, hadith,

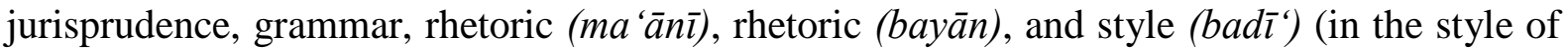
Arabs, not in the style of Persians and philosophers); and I believe that what I attained in these seven sciences (with the exception of jurisprudence) was never attained by any of my teachers, let alone others. I do not make this claim for jurisprudence, for there my teacher (that is al-Bulqīnī) has a wider perspective." He also claimed mastery, though to a lesser degree, of ușul al-fiqh, polemics, morphology, division of inheritances, elegant prose writing, letter-writing, Quranic recitation, medicine, and accounting. He consciously avoided the "sciences of the ancients," particularly logic.

Al-Suyūṭ̂̀ came to feel that he had been born into an age of widespread ignorance and scholarly decline, and that as the most knowledgeable person of his time he had a special mission to assemble and transmit the Islamic cultural patrimony before it disappeared entirely

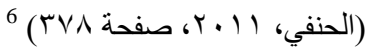


due to the carelessness of his contemporaries. This consciousness of his own superiority led him to make several very controversial claims.

Al-Suyūțī's conviction that "he alone, in an age of increasing ignorance, was a true scholar" first led him to claim that ". . . the tools of ijtihād have been perfected in me-I say that praising God and not out of pride." Al-Suyūṭ̂ি noted that one could be a mujtahid in one field but not necessarily another, acknowledging that "most people are not aware of ijtihād in hadith and Arabic, but are aware of ijtihād in shari'ah only." Al-Suyūṭ̂̄, however, claimed ijtihād in all three of these fields, a rank unequalled, in his view, by anyone since the time of al-Subkī (d 756/1355).

The rejection of this claim by most of his contemporaries led al-Suyūṭ̂̀ to explain himself in the face of what he felt was their misunderstanding. Their accusation that he had claimed unrestricted, independent $i j t i h \bar{a} d$ like that wielded by the four imams who had founded the major schools of law was false. Rather, he was entitled to "derivative" (muntasab) unrestricted ijtihād within his madhhab: "When I attained the rank of unrestricted ijtihād, I did not depart in giving legal opinions from the madhhab of al-Shāfi' 'i.",

Al-Suyūṭ̂̄ set out his claim to ijtihād at length in his al-Radd 'alá Man Akhlada ilá al-Arḍ wa-Jahila anna al-Ijtihād fi Kull 'Așr Fard [Refutation of those who abide on the earth and are ignorant of the fact that ijtihād is a duty in every age]. As the title implies, al-Suyūtî believed that anyone who denied the possibility of ijtihād was ignorant; it is a collective duty (fard kifäyah) which he, as the only qualified person, was discharging on his contemporaries' behalf. He admitted, however, that while most of his opposition came from those who mistakenly denied the possibility of the current existence of any mujtahid, another group admitted that possibility but considered al-Suyūṭi unworthy of it.

Al-Suyūțī's conviction of his intellectual superiority, indeed uniqueness, grew until he was impelled to make a yet bolder claim: to be the restorer of religion (mujaddid) expected at the end of every century:

... I hope . . . to be the mujaddid at the end of this ninth (fifteenth) century, just as al-Ghazālī had hoped for himself, because I alone have mastered all kinds of different disciplines, such as Qur'ānic exegesis and its principles, Prophetic tradition and its sciences, jurisprudence and its principles, language and its principles, syntax and morphology and their principles, polemics, rhetoric and good style, and history. In addition to all this, there are my outstanding, excellent works, the like of which nobody has written before, and their number up till now is about 500. I have originated the science of the principles of language (ușül al-lughah) and its study, and nobody has preceded me in this. It follows the same lines as Prophetic tradition and principles of jurisprudence. My works and my knowledge have travelled to all countries, and have reached Syria, Rūm, Persia, the Hijaz, the Yemen, India, Ethiopia, North Africa, and Takrūr, and have spread from Takrūr to the ocean. In all that I have mentioned, I have no equal, nobody else living has mastered the number of disciplines that I have, and, as far as I know, nobody else has reached the rank of unrestricted ijtihād except for me.

Undaunted by his contemporaries' reaction to this claim, which will be discussed below, alSuyūṭi went on to convince the shadow 'Abbasid caliph, al-Mutawakkil 'alá Allāh 'Abd al'Azīz, to appoint him qadi-in-chief over all qadis in all the lands of Islam, with the power to 
appoint and dismiss whomever he liked. When the qadis predictably rose in outraged protest, the caliph backed down and rescinded the appointment, saying, "What part did I have in this? It was the shaykh Jalāl al-Dīn who persuaded me that it was desirable; he said that this was an ancient post, and the caliphs used to grant it to whomever they chose among the ulama." Uncharacteristically, al-Suyūtị unfortunately does not seem to have left an account of this affair from his point of view; one can only speculate that it represented another aspect of his attempt to secure recognition as the foremost scholar of his time.

It appears that this recognition was more readily granted by those who were separated from al-Suyūṭ̂ by either distance or time. He was widely revered outside of Egypt, and a great proportion of his writing consists of the fatwás he issued in response to requests from abroad. After his death a superstitious awe began to accrue to the scholar, at least according to his student Ibn Iyās, who reported that upon his death, some people bought his shirt and cap, hoping to obtain blessing through them. There were even claims of miracles circulated, which purportedly al-Suyūtī had requested be kept secret until after his death. These included the report of a servant that he and his master had miraculously been transported in an instant to Mecca and then just as quickly returned to Cairo, and prediction of the Ottoman invasion and subsequent ruination of Egypt in 923/1517.

Among al-Suyūṭi's contemporary peers, however, his own pupils seem to have been somewhat isolated in their great admiration and respect for the man. His arrogance and combative personality made it virtually impossible for other scholars to appreciate his undeniable accomplishments, and his more extravagant claims in particular were met with outrage and scorn. His professional life consisted largely of disputes with other scholars (another large body of his writing consists of refutations of others' opinions, numerous titles beginning with Al-Radd 'alá ... ).

Perhaps the most powerful individual with whom al-Suyūṭi was in conflict was Ibn al-Karakī, a favorite of the sultan Qōytbāy — a conflict that caused him serious difficulties. His bitterest rival, however, appears to have been al-Sakhāwī. Al-Sakhāwī's entry on al-Suyūṭ̂ in his biographical dictionary, Al-Ḍaw' al-Lāmi' li-Ahl al-Qarn al-Tāsi', drips with vitriol. He accused al-Suyūṭi firstly of plagiarism: “. . . he would take . . . a lot of earlier works in various fields which were not well known to his contemporaries, change a little bit, and then present them attributed to himself, and make a great fuss in presenting them such that the ignorant would suppose them to be something unequalled." He added sarcastically, "If he were going to steal them, I wish at least he had not distorted them-if he had just copied them it would have been more useful."

Al-Sakhāwī went on to denigrate al-Suyūṭ̂ি's mastery of grammar (of which, we may recall, al-Suyūtị was particularly proud) by accusing him of phonetic corruption (tahrîf) and misspelling or misplacement of diacritics (tashĭf). This he attributed to al-Suyūtīis faulty education which resulted from his having acquired much of his learning by reading independently rather than receiving it orally from a teacher. Al-Sakhāwī was particularly scornful of al-Suyūtị̂'s claim to ijtihād; and not al-Sakhāwī alone but, he claims, "Everybody rose against him when he claimed ijtihād." In fact, al-Sakhāwī said, the claim was made "to cover up his mistakes." In sum, al-Sakhāwī admitted grudgingly that al-al-Suyūṭ̄ was "quick at writing," but his truly distinguishing feature was his "folly and excessive arrogance, even to his mother, so that she continually complained of him." 
As noted before, al-Suyūṭi seems to have been appreciated best at a distance. The sufi writer al-Sha'rānī (d. 973/1565), for instance, venerated al-Suyūṭi and wrote of him, "He was the most knowledgeable person of his time in the sciences and arts of hadith." Complimentary entries on him appear in many later biographical dictionaries and histories, from that of his pupil Ibn Iyās (d. ca. 930/1524) through al-Ghazzī (d. 1061/1651) and Ibn al-'Imād (d. 1089/1679). The centuries following al-Suyūṭ̂i's death are replete with abridgements, commentaries, and supercommentaries on his works (the pre-modern counterpart to our secondary literature).

With the rise of European interest in Islamic history and literature, al-Suyūṭ̄ came in for his share of the disdain generally heaped on all authors post-dating the "golden" Abbasid period. Ignaz Goldziher (d. 1921), for instance dismissed a lifetime of work with the scathing comment: “. . . our ingenious al-Suyūṭi did not shrink from drawing up treatises which, at a cursory glance, purport to have no other end than the elucidation of the subject set down on the title page, but which, on closer examination, prove to be nothing other than polemical works whose sole purpose is to serve as an exaggerated advertisement for their author and as instruction to his contemporaries in his unsurpassed and unsurpassable greatness and erudition."

Goldziher apparently shared al-Suyūṭî's contemporaries' outrage at his daring to claim the right of ijtihād as well as the status of the most learned man of the time:

Even if a not inconsiderable degree of vanity and self-esteem is required to list the description of his own life and scholarly labors among the biographies of the mujtahidūn - a vanity which is best illustrated by the pompous style and manner in which al-Suyūtī speaks of his own works and refers to his own academic career-this is to a large extent overshadowed by the almost nauseating kind of self-adulation we find in his lesser works.

Despite his ability and diligence, and despite the value of his achievement, he must naturally have become an insufferable figure to many of his learned contemporaries, to whom the circumstance of his laying claim to all merit for himself seemed to detract from their own worth.

Many earlier modern Arab scholars, and some up till the present, share this assessment, though without Goldziher's venomous and curiously personal dislike. They tend to dismiss alSuyūṭ̄ as a mere compiler. Sa dī Abū Jīb, for instance, while titling his article "Al-Suyūṭ̂ি: Allāmat "Așrih" [al-Suyūṭ̂: the most erudite of his age], opined that al-Suyūṭî's writings are not innovative nor do they show creative thought; this is only to be expected as that was the style for scholarly writing in his day. His value lies in the fact that he preserved for us earlier writings that were otherwise destroyed by the Mongol invasions and the fall of Spain.

Al-Suyūṭ̂̄'s modern Western biographer, Elizabeth Sartain, cautiously agreed, at least partially, with this negative evaluation of scholarship in the Mamluk age and, by extension, that produced by al-Suyūṭi. While defending al-Suyūṭi against al-Sakhāwī's charges of plagiarism, Sartain deferred final judgment as to the "originality" of his work to "specialists in the fields of Muslim learning in which he wrote." She did note that the age's emphasis on oral transmission and memorization helped to discourage original thought, and concluded that despite the favorable conditions, and "in spite of the great activity of scholars, few outstanding contributions to knowledge were made, and by al-Suyūțī's time there was evidence of steady decline in academic standards." 
In contrast, and perhaps in reaction to this, in recent times there has been what might be termed a revival of interest in al-Suyūṭi and his work. An only moderately intensive search for books and articles dealing exclusively or substantially with the subject of al-Suyūtị yielded a total of 192 titles, the vast majority written within the last thirty years. Following the traditional path, many of these are commentaries (s. sharh) on specific works. Others discuss al-Suyūțî's sources and methodology in his endeavors in such fields as Quran commentary, philology, jurisprudence, and history, while still others attempt to evaluate his contributions and his significance as a scholar to those fields.

Two international conferences devoted solely to al-Suyūṭi have been held in Egypt, one in 1976 and a second in 1993, the latter commemorating the five hundredth anniversary of alSuyūțī's death. (That same year an entire issue of the journal Al-Turāth al- 'Arabī was devoted to articles treating various aspects of his life and work.) While the first conference was attended only by Egyptian participants, the second widened its scope to include contributors from a wide range of Muslim countries: Egypt, Syria, Jordan, Palestine, the United Arab Emirates, Saudi Arabia, Turkey, Azerbaijan, Morocco, Kuwait, Pakistan, Senegal, Malaysia, Qatar, Iraq, and Tunisia. Neither, however, included any Western participants, and the papers published in the proceedings of both conferences (which treated basically the same themes as other literature on al-Suyūṭ̂) showed virtually no awareness of, or perhaps interest in, Western contributions to al-Suyūṭ̂̄ studies.

Spokesmen for both conferences expressly stated that their purpose was to "revive" the memory of al-Suyūṭi, which had been unfairly allowed to lapse. The second conference went on to lay out a number of ambitious goals in this regard. These included, among others, organizing competitions (with prizes) for students carrying out al-Suyūṭ̂̄ studies; production of a film on al-Suyūṭī; translating some of his works into world languages; urging journalists and other disseminators of information in all Islamic countries to educate the people about alSuyūțî's contributions to Islamic culture; and enlisting the cooperation of various Muslim institutions to revive al-Suyūṭ̂̄'s beloved ijtihād.

Some Western scholars as well have become more appreciative of the value of al-Suyūṭi's work. For instance, Éric Geoffroy's 1997 Encyclopaedia of Islam article on al-Suyūṭ̂̄ disputes the widespread condemnation of al-Suyūṭi as merely a compiler. No doubt he did do a great deal of compiling, extracting, summarizing, and commenting on earlier works (including his own) in keeping with his perceived mission of preserving the Islamic scholarly heritage. Yet he went beyond that, according to Geoffroy: ". . . he prefigures the modern period by certain aspects, such as being partly an autodidact, presenting to a public, which he wanted to be widened, manuals which were centered around precise themes. . . . He indeed takes up themes which were usually neglected in Islamic literature. . . . As for form, al-Suyūṭī's procedure is scientific in so far as he quotes his sources with precision and presents them in a critical way. In the introduction to a work, he often defines the method which he is going to follow. His works benefit from a clear structure, and he often broke new ground by expounding his material according to its alphabetical order."

In any discussion of al-Suyūṭ̂, one is bound to express admiration, whether frank or grudging, and astonishment at the sheer massive quantity of his literary output. Al-Suyūṭi incorporated lists of his own works in other works on several occasions, and the biographies written by his students al-Shādhilī and al-Dāwūdī contained such lists approved by him. These lists differ from one another, ranging in size from 282 to 561 titles. Later biographical 
descriptions of al-Suyūṭi almost always include a count of his works if not a list; these range up to the nearly one thousand titles claimed (but not listed) by Ibn al-Qōḍi (d. 1025/1616).

The first modern Western attempt to compose a list of al-Suyūṭī's works, drawing from various sources, was carried out by Gustav Flügel in 1832, and named more than 500 titles. Carl Brockelmann (who was concerned only with extant manuscripts) listed 415. Since then a number of works have been devoted to the question of al-Suyūṭi's production and to attempting to pin the list down. Each list contains, and omits, works respectively omitted and contained in other lists.

Elizabeth Sartain, in her work on al-Suyūțî's autobiography, detailed the difficulties that preparing a definitive list of his works would entail:

At one stage of my research, I had hoped to be able to prepare a complete list of al-Suyūtīis works. Regrettably, this turned out to be impossible. Al-Suyūṭ̂t's works number altogether some 600; one could conceivably prepare an accurate and complete list even of so large a number of works, were it not for the obscurity and confusion concerning the exact titles and subjects of many of them. Some of these problems can be solved by reference to existing MSS, other obscurities cannot be clarified because the works concerned have been lost. This confusion has several causes: firstly, many of the works have more than one title, for instance, a book referred to in one context by its proper title, may be mentioned in another context merely as "Commentary on such-and-such a work" or "Treatise on such-and-such a subject". These titles then become recorded in lists of al-Suyūtiti's works as if they are separate works. I suspect that al-Suyūṭi himself occasionally made this mistake in his own lists of his works, and certainly Brockelmann's list has several examples of such confusion. Secondly, it was al-Suyūṭi's habit to rewrite his works, to abridge them, sometimes more than once, to issue parts of a larger work separately, and sometimes to join short works together in a larger one. This means that there may be two or more works on exactly the same subject, sometimes with very similar titles; once the titles are misrecorded by copyist or cataloguer, it becomes impossible to distinguish between them except by reading them, if copies have survived and are accessible. The task of drawing up a list of al-Suyūṭi's works would be easier if he had written less; as it is, anyone who embarks on this task will be obliged to consult many of those MSS of al-Suyūtị's works which have survived, and these probably run into thousands, scattered in libraries all over the world.

Although valiant efforts have been made in this direction, notably by Ahmad al-Sharqōwī Iqbāl and Muhạmmad Ibrāhīm al-Shaybān̄̄ with Ahmad Sa'īd al-Khāzindār in their identifications of extant manuscripts, it appears that for the matter to be solved (to the extent possible given the survival or lack thereof of any given work) it would require implementation of the primary recommendation set forth at the 1993 conference. This called on ISESCO (the Islamic Educational, Scientific, and Cultural Organization) to appoint a committee of experts to prepare a detailed, indexed list of al-Suyūtị̂'s works, indicating manuscript locations of extant works, and date and place of publication of published titles.

How was it possible for one man to produce such a huge quantity of work? 'Ișām al-Dīn 'Abd al-Ra'ūf admonished us not to dismiss this as impossible; after all, al-Suyūṭi began writing at the age of seventeen and spent the last years of his life in seclusion, totally devoted to his work of composing and editing. Moreover, as Sartain and others have noted, al-Suyūṭ̂ি often divided single works into sections, giving each section a separate title. Al-Sakhāwī sniffed, "He [al-Suyūṭ̂̄] mentioned that his compositions exceed three hundred books. I saw 
of them what consisted of a single sheet of paper [e.g., a fatwá]; as for those that are less than one quire, they are many." To be fair to al-Suyūtịi, though, we must note that conversely a number of his works consist of many volumes. Clearly there is no getting around the fact that the man was extraordinarily productive.

The range of subjects which al-Suyūṭī covered is equally impressive. Lists of al-Suyūṭ̂i's works are typically divided by subject. His student al-Shādhilī's list, approved by the master himself in the year 904/1498-99, for instance, is classified as follows: Quran commentary and what relates to it, 37 titles; hadith and what relates to it, 207 titles; what is related to the terminology (muștalah) of hadith, 24 titles; jurisprudence, 73 titles; principles of jurisprudence, principles of religion, and sufism, 17 titles; philology, grammar, and morphology, 57 titles; rhetoric, 7 titles; works combining various subjects, 10 titles; literature, anecdotes, prose composition, and poetry, 97 titles; and history, 32 titles. This is virtually a syllabus of classical Islamic scholarship.

What, then can be said about the true value, the quality as opposed to quantity of this vast corpus? Al-Suyūṭ̄ clearly considered his work qualitatively and not just quantitatively superior to that of any of his peers: "It is my wont to write only on matters in which I have no precursor and then to exhaust the subject completely." Yet he never claimed to have authored four or five or six hundred weighty tomes. He was well aware of the different levels of significance of his various works (one might quibble with his decision to award a title to a one-page fatwá and list it as a "work"). A valuable glimpse into his thinking is provided by his list of his own works that appears in his autobiography Al-Tahadduth bi-Ni'mat Alläh. This list, unlike all others including those drawn up by him, is divided not by subject matter, but into seven classes delineated by worth and degree of originality.

Al-Suyūṭi described the first class of his works as follows: "Those for which I claim uniqueness. The meaning of this is that nothing comparable has been composed in the world, as far as I know. This is not due to the incapability of those who came before-God forbidbut it simply did not happen that they undertook anything like it. As for the people of this age, they cannot produce its like due to what that would require of breadth of vision, abundance of information, effort, and diligence."

This section consists of 18 titles:

Eight in the field of philology and grammar:

"Jam' al-Jawāmi' fì al-'Arabīyah"

Its commentary, entitled "Ham' al-Hawāmi"”

"Al-Ashbāh wa-al-Nazāà'ir fī al-Qawā'id al-'Arabīyah," also entitled

"Al-Mașā'id al-'Alīyah fī al-Qawā'id al-'Arabīyah"

"Al-Silsilah fī al-Naḥw"“Al-Nukat 'alá 'Al-Alfìyah' wa-'Al-Kāfiyah' wa-'AlShāfiyah' wa-'Al-Shudhūr' wa-'Al-Nuzhah'" in one composition

"Al-Fath al-Qarīb 'alá 'Mughnī al-Labīb"”

"Sharh Shawāhid 'Al-Mughnī”"

"Al-Iqtirāh fĩ Ușūl al-Naḥw wa-Jadaluh"

Six in the field of Quran and its commentary:

"Al-Itqōn fì 'Ulūm al-Qur'ān"

"Al-Durr al-Manthūr fì al-Tafsīr bi-al-Ma'thūr"

“Tarjumān al-Qur'ān" 
"Asrār al-Tanzīl"

“Al-Iklīl fì Istinbāt al-Tanzīll"

Tanāsuq al-Durar fì Tanāsub al-Āyāt wa-al-Suwar

One each in hadith, biography, jurisprudence, and a rebuttal of logic and scholastic theology:

"Nukat al-Badī' āt 'alá 'Al-Mawḍū'āt'"

“Ṭabaqōt al-Nuhāh al-Kubrá," entitled "Bughyat al-Wu’āh"

“Al-Jāmi' fì al-Farā'iḍ,” incomplete

"Ṣawn al-Manțiq wa-al-Kalām 'an Fann al-Manțiq wa-al-Kalām”

Subsequent generations have agreed with al-Suyūṭi's esteem for these 18 works. All of them were valued enough to be represented by extant manuscripts; the value accorded to them in more recent times can be gauged by the fact that all but 3 of them have been published (some many times).

Al-Suyūṭī described his second class as one "for which comparable works have been composed, and a very learned person could produce its like. This class includes works of which at least a volume, more or less, was completed," though some of them are labeled "unfinished." This class comprises 50 titles; many of these are abridgements of Suyūṭi 's or others' works, abridgements of abridgements, and commentaries on commentaries. Of these, 38 titles are extant, and 30 of these titles have been published.

Class three consists of 60 works of small size, ranging from 2 to 10 quires (s. kurrāsah). Of these, 55 are extant, and only 17 of them remain unpublished.

Class four comprises quire-length works, excluding fatwás. al-Suyūṭī listed here 102 works, including 59 extant works of which 32 have been published. This section includes, among other things, his many maqōmät, which are not here listed individually under their separate titles but have often been so listed and so published.

Fatwás are gathered into a class of their own. Al-Suyūṭ̂ characterizes them as being of the size of "quires - more or less," though as we have seen they could be "less" than a quire to the extent of being a single page. There are 80 titles here; of these, a surprising 67 are extant and 60 have been published (though most often in compilations, not separately).

Al-Suyūtị̂'s class six is quite interesting. These, he said, are "compositions that I do not count because they are of the type done by idlers who are interested merely in transmitting, which I composed at the time I was studying and seeking ijäzahs - although they contain good points compared to what other people write." Most of these 40 titles are "muntaqás" [selected extracts] of other works; indeed, they appear to be little more than al-Suyūțī's study notes. Not surprisingly, only 8 are extant, none of them published.

The final class consists of works "which I started then lost interest in, having written only a little." These 83 titles again seem mainly to consist of notes and study aids: abridgements, marginal notes on commentaries and supercommentaries, versifications, no doubt to aid in memorization. Of these 15 still exist and 6, all on the subject of hadith, have even been published.

This gives us a snapshot, based on one listing, of the place of al-Suyūtị̂'s works in Islamic scholarship. We can attempt to judge the value placed on a given work by succeeding 
generations by seeing whether or not that work was copied and has left surviving manuscripts. As mentioned earlier, a number of attempts have been made to identify the existence and location of manuscripts of all of al-Suyūtịi's works.

In turn the judgment of more modern times on the worth of a certain work is evidenced by publication or lack thereof. I have come up with a list of 392 works written by al-Suyūṭ̂ that have been published at least once, without counting additional editions of the same title. Surely the production of such a huge number of works judged worthy of publication is a tremendous achievement.

It is an interesting though probably ultimately futile exercise to seek a definitive enumeration of the individual works within the corpus of al-Suyūtitis literary production and to trace the existence and location of their manuscripts and history of publication. However, stepping back now to focus on the forest instead of the trees, al-Suyūṭi gave the world an enormous quantity of scholarly material, saving and transmitting treasures of the Islamic cultural heritage but also adding his own valuable contribution to it.

\section{Acknowledgment}

This work is dedicated to my great academic's advisor Surotul Ilmiyah, of her amazing inspiring, motivating, and guiding my research, nor for her endless shaping my mindset and developing my skill.

\section{References}

Norris, H. T. (1976, October). E. M. Sartain: Jalāl al-dīn al-Suyūṭī. (University of Cambridge Oriental Publications, Nos. 23-4.) 2 vols.: Xi, 242; [ii], 384, [6] pp. Cambridge: University Press, 1975. Bulletin of the School of Oriental and African Studies, 39(3), 653-5.

Sartain, E. M. (1975). Jalāl al-dīn al-Suyūṭ̄i. Cambridge: Cambridge University Press.

$$
\begin{aligned}
& \text { جلال الدين عبد الرحمن بن أبي بكر بن محمد الخضيري السيوطي. (9V0 ( ). التحدث بنعمة الله تعالى. القدس الثرقية: }
\end{aligned}
$$

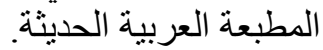

$$
\begin{aligned}
& \text { زين العابدين محمّد بن أحمد ابن إياس الحنفي. (11) (1). بدائع الزهور في وقائع الدهور (r). القاهرة: الهيئة المصرية } \\
& \text { العامة للكتاب. }
\end{aligned}
$$

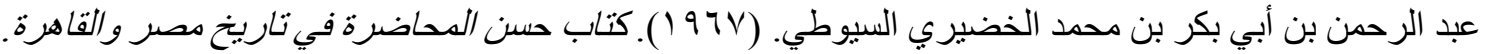

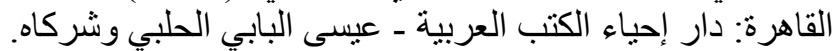

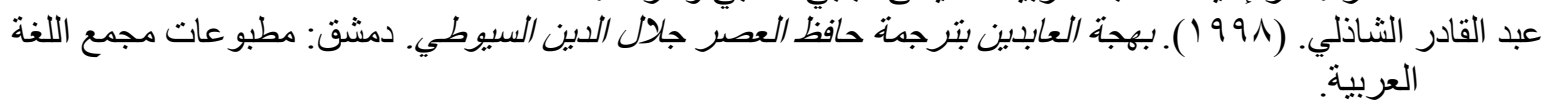

